\title{
Different Regulation of Clonal Growth by Transforming Growth Factor- $\beta 1$ in Human Fetal Articular and Costal Chondrocytes
}

\author{
ROLF E. BRENNER, ANDREAS NERLICH, EBERHARD HEINZE, ULRICH VETTER, AND \\ WALTER M. TELLER \\ Universitätskinderklinik Abteilung I, 7900 Ulm. Germany [R.E.B., E.H., W.M.T.]: Pathologisches Institut der \\ Universität, 8900 Munchen, Germany [A.N.]: and National Institutes of Health, NIDR. \\ Bethesda, Maryland 20892 [U.V.]
}

\begin{abstract}
The variable affection of rib and limb growth in human skeletal dysplasias suggests the presence of sitespecific regulatory mechanisms for chondrocyte proliferation. We therefore studied the clonal growth of normal human costal and articular chondrocytes from the same four fetuses (15 to $30 \mathrm{wk}$ of gestation) in a semisolid medium ( $0.8 \%$ methylcellulose) with a basal supplementation of $5 \%$ heat-inactivated FCS. IGF-I $[0.3-12.5 \mathrm{ng} / \mathrm{mL}$ $(0.04-1.6 \mathrm{nmol} / \mathrm{L})]$, IGF-II $[0.3-12.5 \mathrm{ng} / \mathrm{mL}(0.04-1.7$ $\mathrm{nmol} / \mathrm{L})]$, and hGH $[0.5-25 \mathrm{ng} / \mathrm{mL}(0.02-1.1 \mathrm{nmol} / \mathrm{L})]$ stimulated clonal growth of articular and costal chondrocytes without site-specific difference. In contrast, a significant difference was found for transforming growth factor$\beta 1$, which proved to be a potent growth factor for fetal articular chondrocytes but did not stimulate or only minimally stimulated fetal costal chondrocytes $[p<0.05$ for $0.3 \mathrm{ng} / \mathrm{mL}(0.01 \mathrm{nmol} / \mathrm{L}) \mathrm{TGF}-\beta 1$ and $p<0.01$ for 1.25 $\mathrm{ng} / \mathrm{mL}(0.05 \mathrm{nmol} / \mathrm{L}) \mathrm{TGF}-\beta 1$ using paired $t$ test]. Preincubation with an IGF-I receptor antibody ( $\alpha$ IR-3) completely prevented the proliferative effect of IGF-I, IGF-II, and $\mathrm{hGH}$, indicating that $\mathrm{hGH}$ acts via autocrine or paracrine induction of IGF. The antibody partly reduced TGF$\beta 1$ action on articular chondrocytes $[p<0.05$ for $0.3 \mathrm{ng} /$ $\mathrm{mL}(0.01 \mathrm{nmol} / \mathrm{L}) \mathrm{TGF}-\beta 1, \mathrm{NS}$ for $1.25 \mathrm{ng} / \mathrm{mL}(0.05 \mathrm{nmol} /$ L) TGF- $\beta 1$ using paired $t$ test]. These results indicate that TGF- $\beta 1$ is involved in the regulation of human fetal growth and has a different effect in ribs and limbs. (Pediatr Res $33: 390-393,1993$ )
\end{abstract}

\section{Abbreviations}

TGF- $\beta$, transforming growth factor $\beta$ IGFBP, insulin-like growth factor binding protein

Skeletal growth of the human fetus is influenced by a number of hormones and growth factors stimulating chondrocyte proliferation (1). Specifically, IGF-I, IGF-II, and insulin are regarded to act as endocrine and paracrine growth factors during fetal life (2-4). In contrast, hGH seems to have no, or a negligible, effect on the skeleton, most probably because of low levels of growth hormone receptors in the fetus $(5,6)$. IGFBP- 1 has been detected in the fetal and neonatal circulation and is produced by cultured human fetal liver explants, suggesting a physiologic role in the

Received March 9. 1992; accepted October 26, 1992

Correspondence and reprint requests: Dr. Rolf E. Brenner, Universitätskinderklinik, Abteilung I, Prittwitzstrasse 43, 7900 Ulm. Germany.

Supported in part by grants of the Bundesministerium fur Forschung und Technologie and the Deutsche Forschungsgemeinschaft ( $\mathrm{Br}$ 919/3-1). regulation of IGF action (7-9). Because IGF-I, IGF-II, and IGFBP have been identified in various human fetal tissues, including the growth plate, an autocrine or paracrine action is supposed $(10,11)$. In vitro studies showed that IGF-I and-even more potent-IGF-II are stimulators of human fetal chondrocyte proliferation (12). Insulin, however, exerted a mitogenic action only at supraphysiologic doses. Therefore, in vivo, the effect of insulin may be indirect via its capacity to regulate IGFBP-1 expression (13).

Recently, the family of TGF- $\beta$, which now comprises five multifunctional proteins, has received growing interest in the study of chondro-osseal development $(14,15)$. The effects of TGF- $\beta 1$ - a $25-\mathrm{kD}$ homodimer-have been studied most extensively; effects on cell differentiation, proliferation, and matrix synthesis have been indicated. The enhanced expression of TGF$\beta$ mRNA in the growth plates of human fetal long bones indicates a role in the regulation of prenatal growth (16).

In human skeletal dysplasias, ribs and limbs can show a different degree of growth retardation $(17,18)$, indicating a sitespecific regulation of chondrocyte proliferation. To test this hypothesis, we studied the effect of IGF-I, IGF-II, hGH, and TGF- $\beta 1$ on clonal growth of articular and costal chondrocytes from four human fetuses. Parallel experiments were performed after preincubation with an IGF-I receptor antibody $(\alpha$ IR-3) to investigate the role of this pathway for the mitogenic action.

\section{MATERIALS AND METHODS}

Materials. Human recombinant IGF-I was purchased from Amersham, Braunschweig, Germany. Pure IGF-II isolated from human serum was generously provided by Dr. R. E. Humbel, Institute of Biochemistry, University of Zürich, Switzerland (19). The monoclonal IGF-I receptor antibody was kindly supplied by Dr. S. Jacobs, Wellcome Research Laboratories, NC (20) and purified, using a protein-A sepharose column (21). Biosynthetic hGH was obtained from Eli Lilly, Indianapolis, IN. Human TGF- $\beta 1$ was purchased from Peninsula, Belmont, CA.

Chondrocyte cultures. Human fetal articular cartilage was obtained from the distal femur and costal cartilage from the lower ribs of the same four fetuses $(15,18,21$, and $30 \mathrm{wk}$ of gestation) after legal abortion and parental consent. There was no evidence of congenital skeletal diseases or chromosomal abnormalities. The studies were performed with approval of the local ethical committee.

The cartilage was cleaned from adherent tissue and dissected into small pieces. Isolation and cell culture conditions have been described previously (12). Briefly, the minced cartilage was digested with trypsin $(500 \mathrm{U} / \mathrm{mL})$ and collagenase CLS II Worthington (300 U/mL, Seromed-Biochrom, Berlin, Germany). After centrifugation, each cell pellet was resuspended in Ham's 
F-10 medium supplemented with $10 \%$ FCS, $200 \mathrm{mmol} / \mathrm{L} \mathrm{L}$ glutamine, and $0.5 \%$ minimum essential medium vitamins (Seromed-Biochrom, Berlin, Germany). Viability of cells was tested by the trypan blue exclusion test (22).

Clonal proliferation of chondrocytes. This assay was performed as previously described (12). It is based on the observation that. in a semisolid medium, chondrocytes are prevented from sedimentation and therefore proliferate by forming colonies. The chondrocytes retain their differentiated phenotype in this threedimensional culture system, indicated by the expression of collagen II (15). Briefly, 1000 chondrocytes per Petri dish $\left(9.6 \mathrm{~cm}^{2}\right.$, Greiner, Frickenhausen, Germany) were incubated with BM Whissler Medium (Boehringer Mannheim, Germany) supplemented with $5 \%$ heat-inactivated FCS, $0.06 \mathrm{nmol} / \mathrm{L}$ netilmicin sulfate, $0.1 \mathrm{mmol} / \mathrm{L} 2$-mercaptoethanol, MEM vitamins, and $0.8 \%$ methylcellulose (Fluka, Buchs, Switzerland). The cultures were incubated for $12 \mathrm{~d}$ at $37^{\circ} \mathrm{C}$ in reduced oxygen atmosphere $\left(5 \% \mathrm{CO}_{2}, 5 \% \mathrm{O}_{2}, 95 \%\right.$ relative humidity). In addition to the basal stimulation with heat-inactivated FCS, various concentrations of IGF-I, IGF-II, hGH, and TGF- $\beta 1$ were tested. In parallel, the assay was performed in the presence of an IGF-I-receptor antibody at a concentration of $2 \times 10^{-10} \mathrm{~mol} / \mathrm{L}$. In preliminary experiments, this concentration was found to completely suppress the action of IGF-I in the concentrations used. An unspecific antibody purified identically, using a sepharose column, had no stimulatory or inhibitory effect on clonal growth of the chondrocytes. After $12 \mathrm{~d}$, the number of colonies was counted and the results were expressed as a percentage of the basal conditions with $5 \%$ heat-inactivated FCS. All experiments were performed in triplicate.

Statistics. Paired $t$ test was used to calculate whether differences exist between the response of articular and costal chondrocytes to the growth factors (SAS statistical program, SAS Institute, Cary, NC).

\section{RESULTS}

Influence of $I G F-I, I G F-I I, h G H$, and $T G F-\beta 1$. Clonal growth of human fetal articular and costal chondrocytes could be stimulated with IGF-I even at the lowest concentration of $0.3 \mathrm{ng} / \mathrm{mL}$ $(0.04 \mathrm{nmol} / \mathrm{L})$. There was no significant difference in response of rib and limb chondrocytes (Table 1).

IGF-II stimulated clonal growth at the lowest concentration of $0.3 \mathrm{ng} / \mathrm{mL}(0.04 \mathrm{nmol} / \mathrm{L})$ in chondrocytes from both locations (Table 1). Similar to IGF-I, there was no significant difference between articular and costal chondrocytes (Table 1).

hGH stimulated clonal growth of chondrocyte from both locations at the lowest concentration used $[0.5 \mathrm{ng} / \mathrm{mL}(0.02$ $\mathrm{nmol} / \mathrm{L})]$. Again, there was no significant difference in the re- sponse of articular and costal chondrocytes (Table 1). TGF- $\beta 1$ was a potent growth factor for human fetal articular chondrocytes. Maximal recruitment and subsequent proliferation resulted in a colony incidence of 200 to $220 \%$ compared with basal conditions. In contrast, costal chondrocytes were not or were only minimally stimulated by $\mathrm{TGF}-\beta 1$ under the same experimental conditions (Table 1).

Preincubation with an IGF-I receptor antibody $(\alpha I R-3)$. Preincubation with the IGF-I-receptor antibody (final concentration $2 \times 10^{-10} \mathrm{~mol} / \mathrm{L}$ ) completely suppressed the stimulation of fetal articular and costal chondrocytes by IGF-I $[0.3-12.5 \mathrm{ng} / \mathrm{mL}$ $(0.04-1.6 \mathrm{nmol} / \mathrm{L})]$, IGF-II $[0.3-12.5 \mathrm{ng} / \mathrm{mL}(0.04-1.7 \mathrm{nmol} /$ L)], and hGH [0.3-12.5 ng/mL (0.02-1.1 nmol/L)]. Preincubation with the same concentration of the IGF-I-receptor antibody resulted in a partial reduction of the stimulation of articular chondrocvtes by TGF- $\beta 1$ and even in a slight inhibition of costal chondrocytes below basal conditions (Table 2).

\section{DISCUSSION}

Clonal growth is characteristic for chondrocytes in vivo and in vitro $(23,24)$. We therefore used an assay system that measures the development of colonies out of single cells to test the hypothesis of a differential regulation of cell proliferation in fetal rib and limb cartilage. We provide direct evidence for such a regulatory difference because TGF- $\beta 1$ was a potent growth factor for human fetal articular chondrocytes but did not stimulate, or only minimally stimulated, costal chondrocytes. These results are interesting in two regards. First. they clearly show that regulation of fetal growth during midterm (15th to 30 th wk of gestation) is site-specific and involves the responsiveness of the target tissue to TGF- $\beta 1$. Secondly, it is important to point out that, under our experimental conditions, the potency of TGF- $\beta 1$ even slightly exceeded that of IGF-I or IGF-II in the case of human fetal articular chondrocytes.

Previous animal studies indicated that TGF- $\beta 1$ may have a role in vertebrate limb development $(25,26)$. The high expression of TGF- $\beta$ in growth plates of human fetal long bones (16) and its ability to stimulate clonal growth of isolated human fetal articular chondrocytes as shown here suggest an additional role for the regulation of skeletal growth of the human fetus.

The signal for the induction of cell proliferation in chondrocytes by TGF- $\beta 1$ does not seem to involve IGF-I, inasmuch as IGF-I was not induced in postnatal rabbit articular chondrocytes by TGF- $\beta 1$ (27). Our results, however, show that in human fetal articular chondrocytes the action of TGF- $\beta 1$-at least in the lower concentration used-can be partially reduced by preincubation with the IGF-I-receptor antibody. This apparent discrepancy may be explained by induction of IGF-II or by differences

Table 1. Influence of IGF-I, IGF-II, hGH, and TGF- 1 I on clonal growth of human fetal costal and articular chondrocytes*

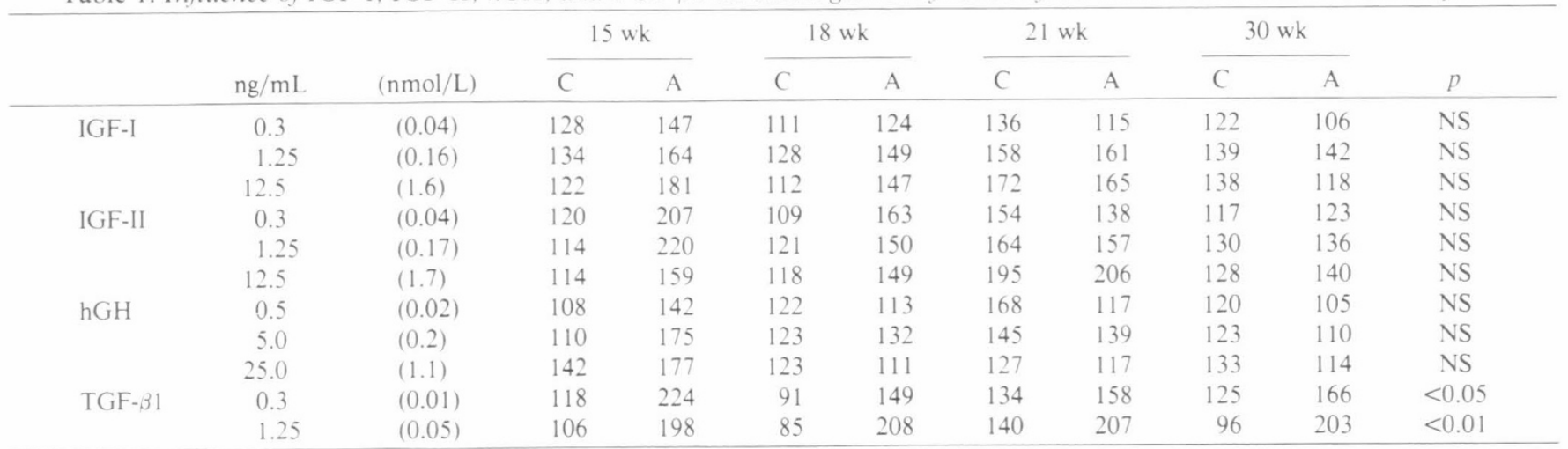

* Values indicate the number of colonies as a percentage of basal conditions. The absolute range of colony incidence under basal conditions was 18-186 colonies out of 1000 cells. The paired $t$ test was used to calculate whether differences between costal and articular chondrocytes were significant. C. costal chondrocytes; A, articular chondrocytes: $p$, paired $t$ test, costal $v s$ articular chondrocytes: NS, not significant. 
Table 2. Influence of IGF-I, IGF-II, hGH, and TGF-ßI on clonal growth of human costal and articular chondrocytes after preincubation with the IGF-I receptor antibody $(\alpha I R-3,2 \times$ $\left.10^{-10} \mathrm{~mol} / \mathrm{L}\right)^{*}$

\begin{tabular}{ccccc}
\hline & $\mathrm{ng} / \mathrm{mL}$ & $(\mathrm{nmol} / \mathrm{L})$ & $\begin{array}{c}\text { Costal } \\
\text { chondrocytes }\end{array}$ & $\begin{array}{c}\text { Articular } \\
\text { chondrocytes }\end{array}$ \\
\hline IGF-I & 0.3 & $(0.04)$ & $96 \pm 10$ & $101 \pm 11$ \\
& 1.25 & $(0.16)$ & $95 \pm 6$ & $99 \pm 5$ \\
IGF-II & 12.5 & $(1.6)$ & $98 \pm 9$ & $101 \pm 13$ \\
& 0.3 & $(0.04)$ & $102 \pm 3$ & $110 \pm 21$ \\
& 1.25 & $(0.17)$ & $101 \pm 1$ & $104 \pm 19$ \\
hGH & 12.5 & $(1.7)$ & $101 \pm 2$ & $103 \pm 7$ \\
& 0.5 & $(0.02)$ & $98 \pm 9$ & $89 \pm 16$ \\
& 5 & $(0.2)$ & $101 \pm 6$ & $90 \pm 9$ \\
TGF- $\beta 1$ & 25 & $(1.1)$ & $100 \pm 8$ & $94 \pm 9$ \\
& 0.3 & $(0.01)$ & $84 \pm 16 \dagger$ & $113 \pm 16 \dagger$ \\
& 1.25 & $(0.05)$ & $70 \pm 13 \dagger$ & $167 \pm 42(\mathrm{NS})$ \\
\hline
\end{tabular}

*Values indicate the number of colonies as a percentage of basal conditions with the same antibody concentration. The absolute range of colony incidence under these basal conditions was 18-195 colonies out of 1000 cells. Results represent the mean \pm SD of four fetuses. The stimulation of proliferation by IGF-I, IGF-II, and hGH was completely suppressed by the antibody. The colony formation of chondrocytes under the influence of TGF- $\beta 1$ was reduced by the antibody. Paired $t$ test was used to calculate whether the reduction was significant in the case of TGF- $\beta 1$. NS, not significant.

$\dagger p<0.05$ (paired $t$ test $v s$ incubations without IGF-I-receptor antibody).

between postnatal rabbit and fetal human chondrocytes in IGFI stimulation. Another possible explanation is that the proliferative affect of TGF- $\beta 1$ on chondrocytes is modulated by serum factors, one of which is epidermal growth factor $(28,29)$. Because IGF peptides are produced by the chondrocyte itself (10), they might be additional factors that partly enhance TGF- $\beta 1$ action on clonal growth of human fetal articular chondrocytes.

The reason for the different effect of TGF- $\beta 1$ on human fetal articular and costal chondrocytes remains unknown so far. One possible explanation may be site-specific differences in TGF- $\beta$ receptors that have been demonstrated in chondrocytes of different zones of the chicken articular growth plate (30).

Colony formation in response to IGF-I and IGF-II was not significantly different in chondrocytes of rib or articular origin, although articular chondrocytes of younger fetuses responded slightly better. A higher number of samples has to be studied to prove or exclude a different age-dependent response to these growth factors. The proliferative effect of IGF-I and IGF-II could be completely prevented by preincubation with the IGF-I receptor antibody. This clearly shows that their effect on clonal growth of human fetal chondrocytes is mediated via this type of receptor.

In contrast to the growing evidence that hGH plays only a minor role in fetal skeletal growth in vivo, hGH stimulated growth of fetal chondrocytes in our assay system even at low concentration. This apparent discrepancy may be based on an increase of growth hormone receptor expression by growth hormone itself during the in vitro assay as observed in the mRNA level in postnatal rat chondrocytes (31). Thus, our results show that human fetal chondrocytes have the ability to respond to hGH under the cell culture conditions applied. However, this might not reflect the in vivo situation. The stimulation of clonal growth by hGH could be completely prevented by preincubation with the IGF-I-receptor antibody. This clearly confirms the notion that the observed effect of $\mathrm{hGH}$ on clonal growth is due to paracrine induction of IGF. Whether hGH additionally stimulates differentiation of human fetal prechondrocytes directly according to the dual effector theory (32) remains an open question.
Acknowledgment. The authors thank M. Schulz for skillful technical assistance.

\section{REFERENCES}

1. Hinchliffe JR, Johnson DR 1983 Growth of cartilage. In: Hall BK (ed) Cartilage, Vol 2. Academic Press. New York, pp 255-295

2. Girard J 1989 Hormonal regulation of fetal growth. In: Senterre J (ed) Intrauterine Growth Retardation. Raven Press, New York, pp 23-33

3. Chard T 1989 Hormonal control of growth in the human fetus. J Endocrinol 123:3-9

4. Gluckman PD, Breier BH, Oliver M, Harding J, Bassett N 1990 Fetal growth in late gestation: a constrained pattern of growth. Acta Pediatr Scand (Suppl) 367:105-110

5. Gluckman PD, Breier BH, 1989 The regulation of the growth hormone receptor. In: Heap RB, Prosser CG. Lamming GE (eds) Biotechnology and Growth Regulation. Butterworth, London, pp 27-33

6. Barnard R, Haynes KM, Werther GA, Waters MJ 1988 The ontogeny of growth hormone receptors in the rabbit tibia. Endocrinology 122:322-326

7. Lassarre C, Hardouin S, Daffos F. Forestier F. Frankenne F. Binoux M 1991 Serum insulin-like growth factors and insulin-like growth factor binding proteins in the human fetus. Relationships with growth in normal subjects and in subjects with intrauterine growth retardation. Pediatr Res 29:219225

8. Wang HS, Lim J, English J. Irvine L. Chard T 1991 The concentration of insulin-like growth factor-I and insulin-like growth factor-binding protein-1 in human umbilical cord serum at delivery: relation to fetal weight. J Endocrinol 129:459-464

9. Lewitt MS, Baxter RC 1989 Regulation of growth hormone-independent insulin-like growth factor-binding protein (BP-28) in cultured human fetal liver explants. J Clin Endcrinol Metab 69:246-252

10. Hill DJ, Clemmons DR, Wilson S, Han VKM, Strain AJ, Milner RDG 1989 Immunological distribution of one form of insulin-like growth factor (IGF)binding protein and IGF peptides in human fetal tissues. J Mol Endocrinol 2:31-38

11. D’Ercole JA, Hill DJ, Strain AJ, Underwood LE 1986 Tissue and plasma somatomedin-C/insulin-like growth factor I concentrations in the human fetus during the first half of gestation. Pediatr Res 20:253-255

12. Vetter U, Zapf J, Heit W, Helbing G, Heinze E, Froesch ER, Teller WM 1986 Human fetal and adult chondrocytes. Effect of insulin like growth factors 1 and II, insulin and growth hormone on clonal growth. J Clin Invest 77:19031908

13. Powell DR, Suwanichkul A, Cubbage ML, DePaolis LA, Snuggs MB, Lee PDK 1991 Insulin inhibits transcription of the human gene for insulin-like growth factor-binding protein-1. J Biol Chem 266:18868-18876

14. Sporn MB, Roberts AB 1990 TGF- $\beta$ : problems and prospects. Cell Regulation $1: 875-882$

15. Roberts AB, Heine UI, Flanders KC, Sporn MB 1990 Transforming growth factor- $\beta$. Major role in regulation of extracellular matrix. Ann New York Acad Sci 580:225-232

16. Sandberg M, Vuorio T, Hirvonen H, Alitalo K, Vuorio E 1988 Enhanced expression of TGF- $\beta$ and $c$-fos mRNAs in the growth plates of developing human long bones. Development 102:461-470

17. Spranger J, Maroteaux P 1990 The lethal osteochondrodysplasias. In: Harris $\mathrm{H}$, Hirschhorn K (eds) Advances in Human Genetics, Vol 19. Plenum Press. New York, pp 1-103

18. Sillence DO, Horton WA, Rimoin DL 1979 Morphologic studies in skeletal dysplasias. Am J Pathol 96:813-859

19. Rinderknecht E, Humbel RE 1978 Primary structure of human insulin-like growth factor II. FEBS Lett 89:283-286

20. Jacobs S, Cook S, Svoboda ME, van Wyk JJ 1986 Interaction of the monoclonal antibodies $\alpha$ IR-1 and $\alpha$ IR-3 with insulin and somatomedin-C receptors. Endocrinology 118:223-226

21. Krugger HJ, Hammond JBW 1988 Purification of immunoglobulins using protein A sepharose. In: Walker JM (ed) Methods in Molecular Biology, Vol 3. Humana Press, Totowa, NJ, pp 363-372

22. Hoskins JM, Menzelle GG, Sanders FK 1956 A comparison of methods for estimating the viable count of a suspension of tumor cells. Exp Cell Res 11:297-305

23. Coon HG 1966 Clonal stability and phenotypic expression of chick cartilage cells in vitro. Proc Natl Acad Sci USA 55:55-73

24. Watanabe K 1970 Changes in the capacity for clonal growth and differentiation in vitro of the vertebral cartilage cells with embryonic development. II Vitalizing effect of conditioned medium. Dev Growth Differ 13:107-113

25. Kulyk WM, Rodgers BJ, Greer K, Kosher RA 1989 Promotion of embryonic chick limb cartilage differentiation by transforming growth factor- $\beta$. Dev Biol 135:424-430

26. Heine UI, Munoz EF, Flanders KC, Ellingsworth LR, Lam HYP, Thompson NL, Roberts AB, Sporn MB 1987 Role of transforming growth factor- $\beta$ in the development of the mouse embryo. J Cell Biol 105:2861-2876

27. Elford PR, Lamberts SWJ 1990 Contrasting modulation by transforming 
growth factor- $\beta 1$ of insulin-like growth factor-I production in osteoblasts and chondrocytes. Endocrinology 127:1635-1639

28. O'Kneefe RJ. Puzas JE. Brand SJ, Rosier RN 1988 Effect of transforming growth factor- $\beta$ on DNA synthesis by growth plate chondrocytes: modulation by factors present in serum. Calcif Tissue Int 43:352-358

29. Vivien D, Galera P, Loyau G, Pujol JP 1991 Differential response of cultured rabbit articular chondrocytes (RAC) to transforming growth factor $\beta$ (TGF$\beta)$ : evidence for a role of serum factors. Eur J Cell Biol 54:217-223
30. Rosier RN, O'Keefe RJ, Crabb ID, Puzas JE 1989 Transforming growth factor beta: an autocrine regulator of chondrocytes. Connect Tissue Res 20:295301

31. Nilsson A. Carlsson B. Mathews L, Isaksson OGP 1990 Growth hormone regulation of the growth hormone receptor mRNA in cultured rat epiphyseal chondrocytes. Mol Cell Endocrinol 70:237-246

32. Green H. Morikowa M. Nixon T 1985 A dual theory of growth hormone action. Differentiation 29:195-198

\section{Announcement}

In view of the appalling events that have occurred in Somalia in the past several months, there is a recognized need in Somalia for medical expertise at the most basic level of pediatric and nutritional care. Moreover, this need is likely to exist for months and even years beyond resolution of the political and social events presently taking place.

Accordingly, you are being asked to join in a volunteer effort to provide medical care to an entire generation of infants and children in Somalia. Due to the current civil unrest in that country, there is no intent to begin provision of such care until order is restored. However, to avoid undue delay at that time, we are asking now for the names of volunteers. By organizing now, it will be possible to mount a meaningful effort within days that might otherwise require months. Because there are thousands of deaths weekly in Somalia, by starting now we may be able to save many thousands of children who will undoubtedly die without us.

Because it is likely that the need for our services will extend beyond a 12-month period, volunteers for 1 to 4 months (or longer), as schedules permit, within the next 24-month period will be gratefully accepted.

For more information, please contact: Karl S. Roth, M. D., or Festus O. Adebonojo, M.D., Department of Pediatrics, Medical College of Virginia, Childrens Medical Center, Box 239, Richmond, VA 23298-0239. 